\title{
Studies on Phenological Development and Yield of Wheat In Relation To Sowing Dates, Seed Priming and Foliar Nutrition
}

\author{
Reena*, Omvati Verma, Subhash Chandra, S.C. Shankhdhar and Poonam Gautam
}

Govind Ballabh Pant University of Agriculture and Technology, Pantnagar, Uttarakhand-263 145, India

*Corresponding author

\begin{abstract}
A B S T R A C T
Field experiment was conducted during rabi season of 2016-2017 and 2017-2018 at G. B. Pant University of Agriculture and Technology, Pantnagar, Uttarakhand. The experiment was conducted in split plot design on wheat variety UP-2565 to study phenological development and yield of wheat in relation to sowing dates, seed priming and foliar nutrition. Main plot treatments consisted of two sowing date i.e. timely (November 28) and late (December 28) and seed priming with $2.0 \% \mathrm{KCl}$ for 12 hours and non-primed seed. Sub plot treatment consisted of foliar treatment including foliar spray of $0.5 \% \mathrm{ZnSO}_{4}, 0.5 \% \mathrm{CaCl}_{2}, 0.5 \% \mathrm{KNO}_{3}, 2.0 \%$ urea and control. Foliar spray was done at maximum tillering and $80 \%$ flowering stage. Results revealed that grain yield reduction in late sown wheat was $22.9 \%$ and $24.0 \%$ during first and second crop season, respectively in comparison to timely sown wheat. Late sown crop showed significant reduction in number of days to attain phenological phases due to effect of high temperature at late vegetative phases. Commencement of days to flowering, anthesis and physiological maturity were 12.4 and 10.3 days (2016-17 and 201718 respectively), 12.1 and 11.3 days (2016-17 and 2017-18 respectively), 9.7 and 8.5 days (2016-17 and 2017-18 respectively) earlier in late sown than timely sown wheat crop. In seed priming treatment occurrence of phenological phases 1.9 to 2.8 days earlier than non-primed seed. There was no significant variation in yield attributes and grain yield due to seed priming. Foliar nutrition resulted significant increment in grain yield over no spray treatment. Grain yield increased by $28.9 \%$ and $23.7 \%$ with $2 \%$ urea, 26.8 and $19.4 \%$ with $0.5 \% \mathrm{ZnSO}_{4}, 21.7$ and $14.6 \%$ with $0.5 \% \mathrm{KNO}_{3}$ and 17.2 and $9.3 \%$ with $0.5 \% \mathrm{CaCl}_{2}$ foliar spray during $1^{\text {st }}$ and $2^{\text {nd }}$ year, respectively. Timely sown wheat responded more to foliar treatment than late sown in relation to increment in grain yield. Foliar spray of $2 \%$ urea in timely (Nov 28) sown crop seemed the most productive combination followed by foliar spray of $0.5 \% \mathrm{ZnSO}_{4}$ in same sowing date. Foliar spray of urea @ $2 \%$ and $\mathrm{ZnSO}_{4} @ 0.5 \%$ treatments were more viable for both the sowing dates and can compensate the yield loss.
\end{abstract}

\section{Ke y w o r ds}

Foliar nutrition,

Grain yield,

Phenological

development, Seed

priming, Sowing

date and wheat

Article Info

Accepted:

20 June 2019

Available Online:

10 July 2019

\section{Introduction}

Wheat is one of the most staple food crops of the world and is a major constituent of global food security. India is the second largest wheat producer in the world. Total area planted wheat in the country about 30.2 million hectare and is produced about 97.4 million tons with productivity of 3.24 tonnes per hectare (Directorate of economics and statistics, MoA \& FW, India, 2016-17). It is estimated that India will have to produce 109 million tonnes of wheat to feed 1.25 billion population of the country by the end of 2020 (Singh, 2010a). With the increased pressure on cultivable land, there is hardly any scope for 
expansion of area under wheat in our country. Therefore, the main emphasis would be on increasing the productivity by adopting the improved cultivation practices and quality inputs. Date of sowing is one of the major yield determining factors in wheat crop due to its main effect on phenological development. Relative duration of phenological stages is an important determinant of grain yield of crop under different growing conditions. Days taken to start booting and anthesis stages notably decreased in late sown wheat due to elevated heat stress later in the season (Nahar et al., 2010). In North western plain zone, there is wider sowing window of wheat. It is sown as early in $2^{\text {nd }}$ fortnight of October, normal in $1^{\text {st }}$ to $3^{\text {rd }}$ week of November and late in $4^{\text {th }}$ week of November to end December. In India, more than $40 \%$ of total wheat area has been shifted to late sowing due to late harvesting of long duration verities of paddy, sugarcane (ratoon), pigeon pea, toria, potato and green vegetables. Due to reduction in tillering period and increased risk of hot weather during grain filling, late planting results in linear reduction in wheat grain yield. At Hisar, Singh et al., (2003) observed that one month delay in sowing of wheat from November 25 to December 25 decreased days taken to anthesis by $14.9 \%$. Rasal and Gavhane (2005) reprted that late sowing of wheat on December 17 reduced the period required for anthesis and physiological maturity as compared to sown on November 17. It has been estimated that delay in sowing of wheat beyond 15 December, results in 50 $\mathrm{kg}$ yield reduction/ha/day (Singh et al., 2001).

Inclusion of improved agronomic practices helps to alleviate adverse effect of temperature under late sown condition. Seed priming is one of the ways to improve seedling vigour and crop establishment under stress conditions (Farooq et al., 2008). They explore the possibility of improving late sown wheat performance by seed priming techniques. In addition to seed priming, foliar nutrition has become an effective way to improve growth, development and yield of a crop. Nutrients play an important role in the biochemical and physiological functions in plant. Foliar applications of nutrients made at early and late vegetative stages will ensure a better canopy, contains high levels of stem carbohydrate being translocated to the developing grain during maturation. Additionally, foliar nutrition promote root absorption of the same nutrient or other nutrients through improving root growth and increasing nutrients uptake by supplying directly to plant foliage (El-Fouly and El-Sayed, 1997). Greater grain yield of wheat was obtained at pre-anthesis foliar feeding with urea $\left(16 \mathrm{~kg} \mathrm{~N} \mathrm{ha}^{-1}\right)$ as compared with later applications (Eman and Borjian, 2010). Gul et al., (2011) also supported the same theory that foliar application of urea at tillering, stem elongation and booting stage increase significantly plant height, spike length, number of grains per spike, 100 grain weight and grain yield. Nitrogen and potassium the major yield limiting nutrients and play a vital role to improve the growth and yield of wheat crop. Abdi et al., (2002) reported that foliar spray of $1 \%$ potassium chloride $+5 \%$ urea at double ridges and milky stages of wheat resulted significantly higher grain yield of wheat as compared to check treatment. Zinc application @ $216 \mathrm{~g} / \mathrm{ha}$ at tillering and booting stage and $0.5 \%$ at tillering and grain initiation stage allowed getting $14 \%$ and $10.4 \%$ yield increment, respectively in wheat grain yield as compared to no spray (Zoz et al., 2012 and Dayanand et al., 2013). Foliar application of $\mathrm{KNO}_{3}(0.5 \%$ and $1.0 \%)$ and $\mathrm{CaCl}_{2}(0.1 \%)$ at booting and anthesis stage improve yield under both normal as well as late sown wheat (Kang et al., 2017 and Chaurasiya et al., 2018).

Information on effect of seed priming and foliar nutrition on phenological development and yield of timely and late sown wheat crop 
is meager. Therefore present investigation was carried out to study the phenological development and yield of wheat in relation to sowing dates, seed priming and foliar nutrition.

\section{Materials and Methods}

Field experiment was conducted at Norman E. Borlaug Crop Research Centre, G. B. Pant University of Agriculture \& Technology, Pantnagar, Uttarakhand, during the rabi season of 2016-17 and 2017-18. Soil of the experimental plot was low in available $\mathrm{N}$, medium in organic carbon, available $\mathrm{P}, \mathrm{K}, \mathrm{Ca}$ and $\mathrm{Zn}$. Soil $\mathrm{pH}$ was near to neutral in reaction. The experiment was laid out in spilt plot design on wheat variety 'UP- 2565' with three replications. The main plot treatment consisted of two sowing date viz. timely (November 28) and late (December 28) and seed priming treatment viz. non primed seeds and seed priming with $2.0 \% \mathrm{KCl}$ for 12 hours. Sub plot treatment consisted of five foliar treatments i.e. control, $0.5 \% \mathrm{ZnSO}_{4}, 0.5 \%$ $\mathrm{CaCl}_{2}, 0.5 \% \mathrm{KNO}_{3}$ and $2.0 \%$ urea. Foliar sprays were made at maximum tillering and $80 \%$ flowering stage. Crop was sown on corresponding dates (November 28 and December 28) using seed rate of $100 \mathrm{~kg} \mathrm{ha}^{-1}$ with a row spacing of $20 \mathrm{~cm}$. The fertilizer was applied @ 120: 60: 40:: nitrogen $(\mathrm{N})$ : phosphorus $\left(\mathrm{P}_{2} \mathrm{O}_{5}\right)$ and potash $\left(\mathrm{K}_{2} \mathrm{O}\right)$ using NPK mixture, urea and muriate of potash.

Half dose of nitrogen and full dose of phosphorus and Potash was applied as basal and rest half dose of nitrogen was applied at crown root initiation after the first irrigation. The rest of the cultural practices were followed as per recommended cultural practices for wheat crop. The weather data during the growing season of wheat in 20162017 and 2017-2018 were obtained from meteorological observatory situated at Norman E. Borlaug Crop Research Centre, G.
B. Pant University of Agriculture \& Technology, Pantnagar, Uttarakhand and are presented in Figure 1 and 2. Data on phonological development stages were recorded in both sowing date from each plot marked with 2 metre row length. The stage of crop when $80 \%$ plant exhibited flowering, anthesis and maturity, that date was recorded. The number of shoots having ear was counted at maturity in marked two metre row length. After harvesting and threshing, the grains were collected and grain yield was recorded in $\mathrm{kg}$ per plot. It was converted to $\mathrm{q} \mathrm{ha}{ }^{-1}$. Data related to phonological development stages and yield were statically analyzed using OPSTAT software developed by Sheoran et al., (1998). Critical difference among treatments was tested at 5\% probability level.

\section{Results and Discussion}

\section{Wheat phenology}

Statistical evaluation of the recorded data on wheat for days to phonological development phases (flowering, anthesis and physiological maturity) showed significant variations due to sowing dates. Results depicted in Table 1 showed that late sowing significantly reduced the number of days to attain corresponding phenological phases in both growing season. Phenological phases are very sensitive to high temperature (Hossain and Teixeira Da Silva (2012). In late (December 28) sown crop, phenological phases viz. flowering, anthesis and physiological maturity occurred 12.4 days, 12.1 days and 9.7 days earlier respectively during 2016-17. Whereas, during 2017-18, corresponding phenological phases occurred 10.3 days, 11.3 days and 8.5 days earlier in comparison to Nov 28 sown crop. The results are in agreement with the work of Dhaka et al., (2006), Nahar et al., (2010) and Mumtaz et al., (2015). Based on mean of two years data from Table 1 found that flowering, anthesis and maturity in late (Dec 28) sown 
wheat was occurred 11.4, 11.7 and 9.1 days earlier in comparison to timely (Nov 28) sown wheat. The faster commencement of flowering, anthesis and maturity in late sown wheat might be due to higher mean maximum temperature existed at late vegetative stages i.e. 45 to $60\left(25.6^{\circ} \mathrm{C}\right), 60$ to $75\left(27.8^{\circ} \mathrm{C}\right)$ and 75 to 90 DAS $\left(30.9^{\circ} \mathrm{C}\right)$ in late sown crop as compared to timely sown crop 45 to 60 $\left(20.1^{0} \mathrm{C}\right), 60$ to $75\left(21.6^{\circ} \mathrm{C}\right)$ and 75 to 90 DAS $\left(25.6^{\circ} \mathrm{C}\right)$ (Figure 1). Rasal and Gavhane (2005) and Nahar et al., (2010) also reported that high temperature stress at late vegetative stages caused significant reduction in number of days to attain aforementioned phenological stages in wheat plant.

During both the years, primed seed took lesser time in occurrence of phenological developmental phases viz. flowering, anthesis and physiological maturity as compared to non-primed seed. In primed seeds anthesis, flowering and physiological maturity occurs 2.5 and 1.9 days, 2.8 and 1.9 days, 2.7 and 2.0 days earlier than non-primed seed during 2016-17 and 2017-18 respectively (Table 1). In primed seeds crop took lesser time to reach flowering and maturity due to early and faster emergence resulting in uniform crop establishment and synchronous growth. The results are in agreement with the study of Kant et al., 2004 and Bose et al., (2016). Although foliar nutrition had non-significant variation in phenological development, numerically more number of days to attain phenological phases recorded in foliar spray of nutrients in comparision to no spray treatment (Table 1). Foliar application of nutrients particularly nitrogen delayed senescence that contributed to more photosynthetic activity reducing the force maturation lead to increased reproductive phase (Amanullah et al., 2013). Interactions effect among sowing date, seed priming and foliar nutrition were nonsignificant in relation to phenological developmental stages.

\section{Grain yield and yield components}

Grain yield was significantly affected by sowing dates and foliar nutrition (Table 2). Their interaction was also significant in this regards (Table 4). In late (December 28) sown crop, grain yield reduced to $22.9 \%$ and $24.0 \%$ during 2016-17 and 2017-18, respectively in comparison to timely (November 28) sown crop. The reduction in grain yield due to late sowing has also been reported by Subhan et al., (2004), Dutta et al., (2005) and Karki (2013). It could be due to high temperature experienced by the late sown crop at late vegetative and grain filling stage shortening the penology. It has also been reported by Sial et al., 2005; Rahman et al., 2009a and Hossain and Teixeira Da Silva, 2012 that wheat phenology and productivity is significantly affected by sowing dates. Faster phenological development in late sown wheat results adverse effect on yield attributes resulting in yield reduction. Timely (November 28) sown crop produced significantly higher number of ear bearing shoots per square metre, spikes per square metre, number of grains per spike and thousand grains weight as compared to late (December 28) sown crop (Table 2). In late sown wheat crop, number of ear bearing shoots per square metre was reduced by $16.8 \%$ and 20.4\% during 2016-17 and 2017-18, respectively; number of spikes per square metre was reduced by $11.1 \%$ and $10.1 \%$ during 2016-17 and 2017-18, respectively; number of grains per spike was reduced by $14.2 \%$ and $13.2 \%$ during 2016-17 and 201718 , respectively and thousands grain weight was reduced by $12.9 \%$ and $12.3 \%$ during 2016-17 and 2017-18, respectively than timely (November 28) sown wheat (Table 2). Late sown crop was exposed to comparatively higher mean maximum temperature during late vegetative stages (Fig. 1) which might be responsible for reduced number of effective shoots. Lesser number of spikes per square metre was recorded in late sown wheat. 
Table.1 Effect of sowing date, seed priming and foliar spray treatment on days taken to flowering, anthesis and physiological maturity in wheat crop

\begin{tabular}{|c|c|c|c|c|c|c|}
\hline \multirow[t]{2}{*}{ Treatment } & \multicolumn{2}{|c|}{ Days to flowering } & \multicolumn{2}{|c|}{ Days to anthesis } & \multicolumn{2}{|c|}{$\begin{array}{c}\text { Days to physiological } \\
\text { maturity }\end{array}$} \\
\hline & 2016-17 & 2017-18 & 2016-17 & 2017-18 & 2016-17 & 2017-18 \\
\hline \multicolumn{7}{|l|}{ Sowing date } \\
\hline Timely (Nov 28) & 90.5 & 87.2 & 95.0 & 91.2 & 121.1 & 119.2 \\
\hline Late (Dec 28) & 78.1 & 76.9 & 82.9 & 79.9 & 111.4 & 110.7 \\
\hline S.Em \pm & 0.8 & 0.4 & 1.2 & 0.2 & 1.4 & 0.9 \\
\hline CD at $5 \%$ & 2.9 & 1.2 & 3.9 & 0.7 & 4.9 & 2.9 \\
\hline \multicolumn{7}{|l|}{ Seed priming } \\
\hline Non primed & 85.5 & 83.0 & 90.4 & 86.5 & 117.6 & 115.9 \\
\hline $2 \% \mathrm{KCl}$ & 83.0 & 81.1 & 87.6 & 84.6 & 114.9 & 113.9 \\
\hline S.Em \pm & 0.8 & 0.4 & 1.2 & 0.2 & 1.4 & 0.9 \\
\hline CD at $5 \%$ & NS & 1.2 & NS & 0.7 & NS & NS \\
\hline \multicolumn{7}{|l|}{ Foliar spray } \\
\hline No spray & 83.1 & 81.6 & 87.8 & 85.1 & 115.1 & 114.5 \\
\hline $0.5 \% \mathrm{ZnSO}_{4}$ & 84.5 & 82.2 & 88.9 & 85.5 & 116.3 & 114.8 \\
\hline $0.5 \% \mathrm{CaCl}_{2}$ & 83.4 & 81.7 & 88.3 & 85.4 & 115.5 & 114.9 \\
\hline $0.5 \% \mathrm{KNO}_{3}$ & 84.7 & 82.2 & 89.6 & 85.8 & 116.8 & 115.2 \\
\hline $2.0 \%$ Urea & 85.7 & 82.7 & 90.0 & 86.0 & 117.4 & 115.3 \\
\hline S.Em \pm & 0.7 & 0.4 & 0.7 & 0.3 & 0.7 & 0.3 \\
\hline CD at $5 \%$ & NS & NS & NS & NS & NS & NS \\
\hline
\end{tabular}

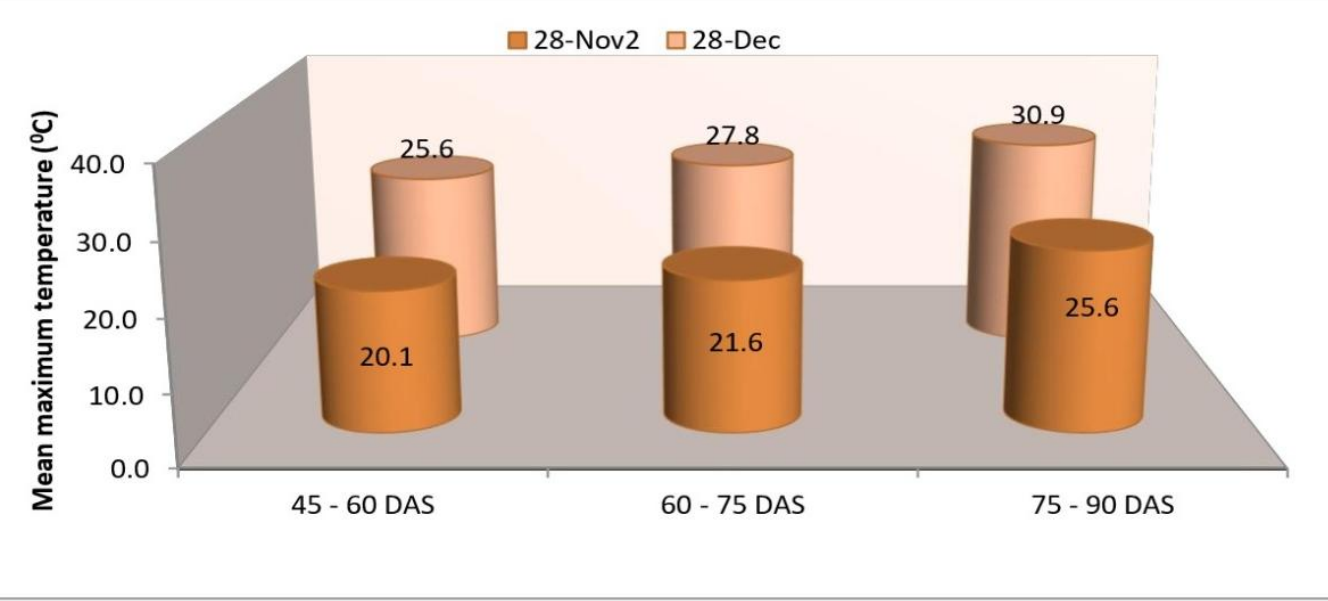

Figure 1: Mean maximum temperature $\left({ }^{\circ} \mathrm{C}\right)$ at different growth stages of timely (November 28) and late (December 28) sown wheat (Mean of two years) 
Table.2 Effect of sowing date, seed priming and foliar spray treatment on number of ear bearing shoots, number of spikes, number of grains per spike, thousand grain weight and grain yield

\begin{tabular}{|c|c|c|c|c|c|c|c|c|c|c|}
\hline \multirow[t]{2}{*}{ Treatments } & \multicolumn{2}{|c|}{$\begin{array}{l}\text { Number of ear } \\
\text { bearing shoots }\left(\mathrm{m}^{-}\right. \\
\left.{ }_{2}\right)\end{array}$} & \multicolumn{2}{|c|}{$\begin{array}{l}\text { Number of spikes } \\
\left(\mathrm{m}^{-2}\right)\end{array}$} & \multicolumn{2}{|c|}{$\begin{array}{l}\text { Number of } \\
\text { grains per } \\
\text { spike }\end{array}$} & \multicolumn{2}{|c|}{$\begin{array}{l}\text { Thousand grain weight } \\
\text { (g) }\end{array}$} & \multicolumn{2}{|c|}{ Grain yield $\left(q\right.$ ha $\left.^{-1}\right)$} \\
\hline & 2016-17 & 2017-18 & $\begin{array}{c}\text { 2016- } \\
17\end{array}$ & 2017-18 & $\begin{array}{c}\text { 2016- } \\
17\end{array}$ & $\begin{array}{c}2017- \\
18\end{array}$ & 2016-17 & 2017-18 & 2016-17 & 2017-18 \\
\hline \multicolumn{11}{|l|}{ Sowing date } \\
\hline Timely (Nov 28) & 423.4 & 408.4 & 300.5 & 282.3 & 52.1 & 46.8 & 47.2 & 41.5 & 50.1 & 45.8 \\
\hline CD at $5 \%$ & 24.6 & 17.7 & 1.9 & 3.2 & 7.0 & 6.1 & 2.3 & 2.4 & 3.1 & 4.2 \\
\hline \multicolumn{11}{|l|}{ Seed priming } \\
\hline Non primed & 384.1 & 361.8 & 283.6 & 267.8 & 46.9 & 41.8 & 43.2 & 38.2 & 43.9 & 40.2 \\
\hline $2 \% \mathrm{KCl}$ & 391.7 & 371.7 & 284.0 & 268.4 & 49.8 & 45.6 & 45.2 & 39.7 & 44.8 & 40.3 \\
\hline No spray & 312.7 & 325.0 & 238.0 & 234.8 & 43.1 & 39.3 & 40.1 & 36.1 & 37.3 & 35.5 \\
\hline $0.5 \% \mathrm{ZnSO}_{4}$ & 413.0 & 382.9 & 295.4 & 276.6 & 50.5 & 46.5 & 45.6 & 39.8 & 47.3 & 42.4 \\
\hline $0.5 \% \mathrm{CaCl}_{2}$ & 389.3 & 362.7 & 294.1 & 275.5 & 45.8 & 40.7 & 44.1 & 38.8 & 43.7 & 38.8 \\
\hline $0.5 \% \mathrm{KNO}_{3}$ & 402.5 & 374.3 & 294.7 & 276.1 & 48.3 & 42.9 & 44.9 & 39.2 & 45.4 & 40.7 \\
\hline $2.0 \%$ Urea & 421.9 & 388.3 & 296.8 & 277.5 & 54.3 & 48.9 & 46.3 & 40.9 & 48.1 & 43.9 \\
\hline S.Em \pm & 6.9 & 7.5 & 0.5 & 0.5 & 1.2 & 1.2 & 0.4 & 0.7 & 0.5 & 0.7 \\
\hline CD at $5 \%$ & 20.1 & 21.5 & 1.4 & 1.3 & 3.6 & 3.4 & 1.3 & 2.0 & 1.5 & 2.2 \\
\hline
\end{tabular}


Table.3 Interaction effect of sowing date and foliar spray treatment on number of effective tillers of wheat

\begin{tabular}{|c|c|c|c|c|c|}
\hline \multirow{3}{*}{ Sowing date } & \multicolumn{5}{|c|}{ Number of effective tillers $\left(m^{-2}\right)$} \\
\hline & \multicolumn{5}{|c|}{ Foliar spray } \\
\hline & No spray & $0.5 \% \mathrm{ZnSO}_{4}$ & $0.5 \% \mathrm{CaSO}_{4}$ & $0.5 \% \mathrm{KNO}_{3}$ & $2 \%$ Urea \\
\hline & \multicolumn{5}{|c|}{ 2016-17 } \\
\hline Timely (Nov 28) & 323.5 & 457.2 & 428.3 & 442.0 & 465.8 \\
\hline Late (Dec 28) & 301.8 & 368.8 & 350.3 & 363.0 & 378.0 \\
\hline \multicolumn{6}{|c|}{ S.Em $\pm=9.9$ CD at5\% $=28.4$} \\
\hline \multicolumn{6}{|c|}{$2017-18$} \\
\hline & \multicolumn{5}{|c|}{90 DAS } \\
\hline Timely (Nov 28) & 339.5 & 431.3 & 412.2 & 422.8 & 408.4 \\
\hline Late (Dec 28) & 310.5 & 334.5 & 313.2 & 325.7 & 325.0 \\
\hline \multicolumn{6}{|c|}{ S.Em $\pm=10.6$ CD at5\%=30.4 } \\
\hline
\end{tabular}

Table.4 Interaction effect of sowing date and foliar spray on grain yield of wheat

\begin{tabular}{|c|c|c|c|c|c|}
\hline \multirow{3}{*}{ Sowing date } & \multicolumn{5}{|c|}{ Grain yield $\left(\mathrm{q} \mathrm{ha}^{-1}\right)$} \\
\hline & \multicolumn{5}{|c|}{ Foliar spray } \\
\hline & No spray & $0.5 \% \mathrm{ZnSO}_{4}$ & $0.5 \% \mathrm{CaSO}_{4}$ & $0.5 \% \mathrm{KNO}_{3}$ & $2 \%$ Urea \\
\hline & \multicolumn{5}{|c|}{ 2016-17 } \\
\hline Timely (Nov 28) & 41.2 & 53.4 & 50.2 & 51.4 & 54.4 \\
\hline Late (Dec 28) & 33.3 & 41.1 & 37.3 & 39.5 & 41.7 \\
\hline \multicolumn{6}{|c|}{ S.Em $\pm=0.7$ CD at $5 \%=2.1$} \\
\hline & & & 2017-18 & & \\
\hline Timely (Nov 28) & 38.4 & 48.8 & 45.6 & 46.7 & 49.6 \\
\hline Late (Dec 28) & 32.6 & 36.0 & 32.0 & 34.8 & 38.4 \\
\hline \multicolumn{6}{|c|}{ S.Em $\pm=1.1 \mathrm{CD}$ at $5 \%=3.0$} \\
\hline
\end{tabular}

It could be due to lesser number of ear bearing shoots resulting from shorten vegetative phases as a result of higher temperature (Hossain and Teixeira de Silva, 2012). Delayed sowing from Nov 28 to Dec 28 exposed to higher mean maximum daily temperature than timely sown crop $\left(26.1^{\circ} \mathrm{C}\right.$ against $21.8^{\circ} \mathrm{C}$ during $2016-17$ and $29.4^{\circ} \mathrm{C}$ against $21.3^{\circ} \mathrm{C}$ during $2017-18$ ) during late vegetative period (one month prior to anthesis). This might have resulted in poor growth of late sown crop coupled with less number of ear bearing shoots and subsequently less number of spikes per square metre. Number of grains per spike is one of the most important component determining yield. It depends on the number of viable florate that set grains at anthesis (PeltonenSainio et al., 2007) and cosequently spikelets fertility. Reduction in number of grains per spike recorded in late (December 28) sown crop could be due to reduction in number of fertile spikelets per spike. Poor grain growth might be due to high temperature in December 28 sown crop at the time of grain development which reduces the activity of starch synthase (Zhao et al., 2007) and remobilization of photoassimilates in to the developing grain (Wang et al., 2011). Furthermore heat stress also shortened the 
duration of grain filling and enhance grain filling rate which in turn reduces grain mass (Tewolde et al., 2006 and Dias et al., 2009a).Significant reduction in number of spikes per square metre, grains per spike and thousand grains weight due to late sowing was also observed by Kumar and Sharma (2003), Shirpurkar et al., (2008) and Malik et al., (2009). As a consequence of which grain yield reduces significantly in late sown wheat in comparison to timely sown wheat.

Seed priming treatment resulted more number of spikes per square metre, number of grains per spike, thousand grains weight and grain yield as compared to non-primed seed. Though the differences were non-significant during both the crop season (Table 2). Giri and Schillinger (2003) and Subedi and Ma (2005) also reported that seed priming with $\mathrm{KCl}$ had no significant increment in yield.

Among foliar spray treatment, the maximum number of ear bearing shoot per square metre, spikes per square metre, number of grains per spike and thousands grain weight were recorded in $2 \%$ urea spray during both the years (Table 2). As a consequences of which during both the years, the highest grain yield 48.1 and $43.9 \mathrm{q} \mathrm{ha}^{-1}$ during 2016-17 and 2017-18, respectively was recorded in $2 \%$ urea spray treatment which was significantly superior to rest of the treatments except $0.5 \%$ $\mathrm{ZnSO}_{4}$. During $1^{\text {st }}$ year of experimentation period, the maximum increment $28.9 \%$ in grain yield was observed with $2.0 \%$ urea spray followed by $26.8 \%$ with $0.5 \% \mathrm{ZnSO}$, $21.7 \%$ with $0.5 \% \mathrm{KNO}_{3}$ and $17.2 \%$ with $0.5 \%$ $\mathrm{CaCl}_{2}$. During $2^{\text {nd }}$ year, same trend was observed in yield increment i.e. $23.7 \%$, $19.4 \%, 14.6 \%$ and $9.3 \%$ with spray of $2.0 \%$ urea, $0.5 \% \quad \mathrm{ZnSO}_{4}, 0.5 \% \quad \mathrm{KNO}_{3}$ and $0.5 \%$ $\mathrm{CaSO}_{4}$, respectively (Table 2).The minimum values of corresponding yield components and grain yield were recorded in no spray treatment during both the years. At the time of grain development, nutrient requirement of developing grain is high. Foliar feeding is one of the ways to meet out adequate and sufficient quantity of nutrients to the developing seed.

Stimulating effect of nutrients on yield could be due to increment in biomass production, more vegetative growth and yield attributes. They involved in photosynthesis, protein metabolism and energy transfer reactions, enhanced metabolism activities, pollination, and fertilization and interfere in the germination and growth of pollen grains resulting in the increment in the number of grains per spike (Krichevsky et al., 2007). Foliar application of urea at the later growth stages of the crop might have increased the availability of nitrogen to the crop which favoured enhanced accumulation of photosynthate in the grains. $\mathrm{Zn}, \mathrm{K}$ and $\mathrm{Ca}$ also involve in accumulation of photosythates in the grain but to smaller extent in comparison to N. Kundu and Sarkar (2009), Zoz et al., (2012), and Chaurasiya et al., (2018) also reported improvement in grain yield and yield components due to foliar spray of urea, $\mathrm{ZnSO}_{4}, \mathrm{KNO}_{3}$ and $\mathrm{CaCl}_{2}$ at late vegetative and reproductive stages.

Interaction between sowing date and foliar spray treatments for number of ear bearing shoots and grain yield was significant during both the years (Table 3 and 4). Persual of data in Table 3 indicates that the highest number of ear bearing shoots recorded in $2.0 \%$ urea spray of timely (November 28) sown crop, while, the minimum was recorded with no spray treatment of late (December 28) sown crop. Foliar spray of $0.5 \% \mathrm{ZnSO}_{4}$ was next to best treatment of $2.0 \%$ urea spray in timely (November 28) sown crop. Similarly interaction table 4 indicates that the highest grain yield obtained in timely (November 28) sown crop with $2 \%$ urea spray and minimum was recorded in no spray treatment of late 
sown crop. During both the years, Late (December 28) sown crop also recorded maximum grain yield with $2 \%$ urea spray which was at par with $0.5 \% \mathrm{ZnSO}_{4}$ spray of late (December 28) sown crop and no spray of timely (November 28) sown crop. Although, study revealed that timely sown wheat responded more to foliar nutrition in relation to improve crop yield but in late sown crop foliar spray also help to mitigate adverse effect of heat stress resulting in higher yield in comparison to no spray treatment. These results are in conformity with the finding of Graham and McDonald (2001) and Singh et al., (2011a).

Based on two year's study, it can be concluded that phenological development and wheat grain yield is sensitive to temperature stress. One month delay sowing from Nov 28 to Dec 28 caused reduction in grain yield by $22.9 \%$ and $24.0 \%$ during $1^{\text {st }}$ and $2^{\text {nd }}$ year of investigation, respectively. Among nutrients spray, foliar spray of $2 \%$ urea resulted significantly higher grain yield than other nutrient spray except $0.5 \% \quad \mathrm{ZnSO}_{4}$ spray. Response to foliar spray of nutrient was more in timely sown than late sown wheat. Foliar spray of $2 \%$ urea in timely (Nov 28) sown crop seemed the most productive combination followed by foliar spray of $0.5 \% \mathrm{ZnSO}_{4}$ in same sowing date. Foliar spray of all nutrients in late (Dec 28) sown wheat can reduce the yield loss by mitigating adverse effect of heat stress. Foliar spray of urea @ 2\% and $\mathrm{ZnSO}_{4}$ @ $0.5 \%$ treatments were more viable for both the sowing dates and can compensate the yield loss

\section{References}

Abdi, M., G. N. Mohamadi and Golchin, A. 2002. The influence of foliar nutrition of urea and potassium chloride on grain yield, grain protein content, yield components and leaf relative water content of Sardari wheat under rainfed condition. J. Agri. Sci. 8: 29-38.

Amanullah, A. Z., A. J. Khan, Z. Shah and Ahmad B. 2013. Foliar application of nitrogen at different growth stages influences the phenology, growth and yield of maize (Zea mays L.). Soil Environ. 32: 135-140.

Bose, B., A. K. Srivastava and Siddique, A. 2016. Impact of nitrate salt hardened seeds and sowing dates on seedling stand, growth, yield attributes, nitrogen and stress metabolism of rice. Int. J. Agric. Environ. Biotechnol. 9 (3): 381392.

Chaurasiya, A., D. Singh, S. K. Dutta, A. R. Chowdhury and Dubey, S. K. 2018. Growth and yield enhancement of wheat through foliar spray of Osmoprotectants under high temperature stress condition. J. Pharmacog. Phytochem. 7(3): 28192825.

Dayanand, S. M. Mehta, R. K. Verma and Rathore, V. S. 2013. Effect of foliar applied thiourea and zinc on the productivity and economics of wheat (Triticum aestivum L.). Int. J. Agricult. Stat. Sci. 9 (1): 339-344.

Dhaka, A.K., A.S. Bangarwa, R.K. Pannu, R.K. Malik and Garg, R. 2006. Phenological development, yield and yield attributes of different wheat genotypes as influenced by sowing time and irrigation levels. Agric. Sci. Digest, 26 (3): 174-177.

Dias, A. S., and Lidon, F. C. 2009a. Evaluation of grain filling rate and duration in bread and durum wheat under heat stress after anthesis. J. Agron. Crop Sci. 195:137-147.

Directorate of Economics and Statistics, Ministry of Agriculture \& Farmers Welfare, GOI, 3rd_Adv_Estimates 2016-17.

Dutta, D., P. Bandyopadhyaya and Banerjee, 
P. 2005. Influence of sowing date and nutrient level on yield and its attributes of wheat (Triticum aestivum). Ann. Agric.Res. 26 (1): 93-96.

El- Fouly, M.M., and El-Sayed, A.A. 1997. Potassium status in the soil and crops, recommendations and present use in Egypt. Proc. Of The Regional Workshop of the International Potash Institute, 26-30 May, 1997, Bornovoa, Izmir, Turkey, Ed. Johnston, A. E., 5065.

Emam, Y., and A.R. Borjian, 2010. Yield and yield components of two winter wheat (Triticum aestivum L.) cultivars in response to rate and time of foliar urea application. J. Agric. Sci. Technol. 2: 263-270

Farooq, M., S. M. A. Basra, H. Rehman and Saleem, B. A. 2008.Seed priming enhances the performance of late sown wheat (Triticum aestivum L.) by improving chilling tolerance. J. Agron. Crop Sci. 194 (1): 55-60.

Giri, G. S., and Schillinger, W. F. 2003. Seed priming in winter wheat for germination, emergence and yield. Crop Sci. 43: 2135-2141.

Graham, A. W., and Mc Donald, G. K. 2001. Effects of zinc on photosynthesis and yield of wheat under heat stress. In Proceedings of the 10th Australian Agronomy Conference (pp. 4-25).

Gul, H., A. Said, B. Saeed, F. Mohammad and Ahmad, I. 2011.Effect of foliar application of nitrogen, potassium and zinc on wheat growth. ARPN J. Agric. Biol. Sci. 6 (4): 56-59.

Hossain, A., and Teixeira Da Silva, J. A. 2012. Phenology, growth and yield of three wheat (Triticum aestivum L.) varieties as affected by high temperature stress. Not. Sc. Bio. 4(3): 97-109.

Kang, J. S., H. Singh, M. Kaur and Kaur, H. 2017. Agronomic techniques and planting system moderate terminal temperature stress in wheat. Int. J. Curr. Microbiol. App. Sci. 6 (6):1011-1017.

Kant, S., S. S. Pahuja and Pannu, R. K. 2004. Effect of seed priming on growth and phenology of wheat under late-sown conditions. Trop. Sci., 44 (1): 9-15.

Karki, B. S. 2013. Evaluation of wheat genotypes for heat tolerance under Tarai conditions of Uttarakhand. Thesis Ph.D. (Agronomy), G.B. Pant University of Agriculture and Technology, Pantnagar (U.S. Nagar), $248 \mathrm{p}$.

Krichevsky, A., S. V. Kozlovsky, G. W. Tian, M.-H. Chen and Zaltsman, A.; Citovsky, V. 2007. How pollen tubes grow. Developmental Biology, Pasadena, 303 (12): 405-420.

Kumar, R., and Sharma, S. N. 2003. Effect of levels of nitrogen on wheat as influenced by date of sowing. Annals of Agri. Res. 24 (1): 104-110.

Kundu, C., and Sarkar, R. K. 2009. Effect of foliar application of potassium nitrate and calcium nitrate on performance of rainfed lowland rice (Oryza sativa). Indian J. Agron. 54 (4): 428432.

Malik, A.U., M. A. A. H. A. Bukhsh and Hussain, I. 2009.Effect of seed rates sown on different dates on wheat under agro-ecological conditions of Dera Ghazi Khan. J. of Anim. and Pl. Sci. 19(3): 126-129.

Mumtaz, M. Z., M. Aslam, H. M. Nasrullah, M. Akhtar and Ali, B. 2015. Effect of various sowing dates on growth, yield and yield components of different wheat varieties. American Eurasian J. Agric. Env. Sci. 15: 2230-34.

Nahar, K., K. U. Ahamed and Fujita, M. 2010. Phenological variation and its relation with yield in several wheat (Triticum aestivum L.) cultivars under normal and late sowing mediated heat 
stress condition. Not. Sci. Biol. 2 (3): 51-56.

Rahman, M. M., A. Hossain, M. A. Hakim, M. R. Kabir and Shah, M. M. R. 2009b. Performance of wheat genotypes under optimum and late sowing condition. Int. J. Sustain. Crop Prod. 4 (6): 34-39.

Rasal, P. N., and Gavhane, V. N. 2005. Differential reaction of wheat genotypes to phenological development, heat unit consumed, thermal use efficiency and grain yield. Res. Crops, 6 (3): 424-428.

Shirpurkar, G.N., M. P. Wagh, and Patil, D. T. 2008. Comparative performance of wheat genotypes under different sowing dates. Agric. Sci. Dig. 28 (3): 231-232.

Sial, M. A., M. A. Arain, S. D. Khanzada, M. H. Naqvi, M. U. Dahot and Nizamani, N. A. 2005. Yield and quality parameters of wheat genotypes as affected by sowing dates and high temperature stress. 2005. Pak. J. Bot. 37 (3): $575-584$.

Singh, A., D. Singh and Gill, B. S. 2011a.Planting time, methods, and practices to reduce the deleterious effects of high temperature on wheat. In: the proceedings of international conference on preparing agriculture for climate change. Punjab Agricultural University, Ludhiana, February, 6-8, pp 338-339.

Singh, M., Ram Niwas, O.P. Bishnoi and Sharma, K. 2003. Phenology of wheat cultivar in relation to thermal indices under different management practices. Haryana Agric. Univ. J. Res. 33: 23-28.

Singh, S., M.C. Jain and Singh, J.P. 2001.
Growth and yield response of wheat culitivars to hyper thermal stress. Indian j. plant Physiol. 6(4): 395-402.

Singh, S.S., 2010a. Wheat production in India and future prospects. In: $8^{\text {th }}$ International wheat conference, June 14, 2010, St. Petersberg, Russia.

Subedi, K. D., and Ma, B. L. 2005. Seed priming does not improve corn yield in a humid temperate environment. Agron. J. 97 (1): 211-218.

Subhan, F., A. Nazir, M. Anwar, N.H. Shah, M. Siddiq, I. Ali, J. Rahman and Sajjad, T. 2004. Response of newly developed wheat cultivars/advance lines to planting dates in the central agroecological zone of NWFP. Asian J. Plant Sci. 3 (1): 87-90.

Tewolde, H., C. J. Fernandez and Erickson, C. A. 2006. Wheat cultivars adapted to post- heading high temperature stress. J. Agron. Crop Sci. 192(2): 111-120

Wang, Y. X., and Frei, M. 2011.Stressed food - The impact of abiotic environmental stresses on crop quality. Agr. Ecosyst. Environ.141: 271-286.

Zhao, H., T. B. Dai, Q. Jing, D. Jiang and Cao, W. X. 2007. Leaf senescence and grain filling affected by post-anthesis high temperatures in two different wheat cultivars. Plant Growth Regul. 51: 149-158.

Zoz, T., F. Steiner, R. Fey, D. D. Castagnara and Seidel, E. P. 2012. Response of wheat to foliar application of zinc. Cienc. Rural, 42 (5): 784-787.

\section{How to cite this article:}

Reena, Omvati Verma, Subhash Chandra, S.C. Shankhdhar and Poonam Gautam. 2019. Studies on Phenological Development and Yield of Wheat In Relation To Sowing Dates, Seed Priming and Foliar Nutrition. Int.J.Curr.Microbiol.App.Sci. 8(07): 2668-2678. doi: https://doi.org/10.20546/ijcmas.2019.807.329 